\title{
Priority and Exclusiveness : Russians and Germans at the Northern Silk Road (Materials from the Turfan-Akten)
}

Ingo Strauch

\section{(2) OpenEdition \\ Journals}

Electronic version

URL: http://journals.openedition.org/edl/676

DOI: $10.4000 /$ edl.676

ISSN: 2296-5084

\section{Publisher}

Université de Lausanne

\section{Printed version}

Date of publication: 15 September 2014

Number of pages: $147-178$

ISBN: 978-2-940331-35-2

ISSN: 0014-2026

Electronic reference

Ingo Strauch, «Priority and Exclusiveness : Russians and Germans at the Northern Silk Road

(Materials from the Turfan-Akten) ", Études de lettres [Online], 2-3 | 2014, Online since 15 September

2017, connection on 18 December 2020. URL : http://journals.openedition.org/edl/676 ; DOI : https:// doi.org/10.4000/edl.676 


\section{PRIORITY AND EXCLUSIVENESS: RUSSIANS AND GERMANS AT THE NORTHERN SILK ROAD (MATERIALS FROM THE TURFAN-AKTEN)}

The collaboration between Russian and German scholars in the archaeological exploration of the Northern Silk Road yielded enormous results, which crucially changed the field of Oriental Studies in the beginning of the 20th century. This bilateral collaboration was part of a larger international endeavour to explore the unique monuments of Eastern Turkestan. Scholars of all leading nations - including British, French and Japanese - sent their expeditions into the oases of Chinese Turkestan to document and collect archaeological objects and manuscripts. However - partially due to the political circumstances during this period, partially due to personal and academic rivalry - the collaboration between Russians and Germans was not entirely free from misunderstandings and conflicts. In particular, a disputed agreement about the definition of "areas of interest" gave rise to a long-lasting controversy, which even today is not completely settled among the scholars involved in the study of Silk Road materials. The article introduces and discusses some new documents from the socalled "Berliner Turfan-Akten" and thus tries to make a contribution to the on-going discussion about this matter.

In the course of the 19th century, the interests of the Russian Empire had extended far into the region called Turkestan, i.e. the areas from the Caspian to the Pamirs and those further east (Eastern Turkestan) known today as Xinjiang, which was officially part of the Chinese Qing Empire. Due to the weakened political power of the Chinese, the Russians started to exert an important political and military influence in this region during the last decades of the 19th century ${ }^{1}$.

I. A comprehensive survey of the political situation of Central Asia is given by Y. Bregel, "Central Asia". More specific studies concerning the political relations 
Today, Xinjiang is an autonomous region in the north-west of the People's Republic of China covering an area of around 1.6 million square kilometres. Its topography is shaped by the great Taklamakan desert, which is intersected by two main roads spreading from the eastern to the western part of the desert. Along these routes, one can find fertile oases. From the beginning of the 1st century AD, these routes formed part of the so-called Silk Road ${ }^{2}$ connecting the Chinese Empire to the West. Due to an active transcontinental trade, people of different ethnicities and manifold religious backgrounds settled here establishing urban and religious centres. The favourable climatic conditions facilitated the conservation of a huge amount of architectural, artistic and manuscript remains. Since the end of the 19th century and prior to the First World War, these remains were systematically explored by a series of expeditions undertaken by German, British, French, Japanese and Russian scholars ${ }^{3}$.

It can be stated undoubtedly that the discovery of the Central Asian archaeological remains opened a new chapter for Oriental Studies. Formerly unknown scripts and languages (e.g. Tokharian, Khotanese, Sogdian, Bactrian and Old Turkic) turned into new topics of research. Also, distinct regional varieties of major religions (e.g. Manichaeism and Buddhism) became accessible as a result of the architectural, artistic and textual remains.

between Russia and Eastern Turkestan at the end of the 19th-beginning of the 20th century include V. A. Moiseev, Rossiia i Kitaj v Tsentral'noi Azii and S. Gorshenina, Asie centrale.

2. Although it is now well-known that silk was not the only and in certain periods not even the most important commodity, I maintain here the term "Silk Road" - a translation of Ferdinand von Richthofen's well-introduced term "Seidenstraße”.

3. The history of this exploration is vividly described in P. Hopkirk's popular monograph Foreign Devils on the Silk Road: The Search for the Lost Cities and Treasures of Chinese Central Asia. A concise, but very informative survey is provided by W. Sundermann, "Turfan Expeditions". The special role of German intellectual history and philology in the study of Central Asian texts and languages is addressed in M. Espagne, "Ot Turfana do Berlina”. Much new material concerning the history of the exploration of Xinjiang is included in the recent volume Russian Expeditions to Central Asia at the Turn of the 20th Century, edited in 2008 in English and Russian by the Russian scholar I. F. Popova. The present paper is in many regards indebted to the enormous amount of sources cited in the contributions of this work. 
Today, fragments of thousands of manuscripts in different scripts and languages and hundreds of paintings are kept in Berlin, London, New Delhi, Paris, Saint Petersburg, Japan and other places. The objects have been and still are studied and explored by researchers around the world - frequently in fruitful international cooperation ${ }^{4}$.

It is not the aim of my paper to give a general evaluation of these activities or to place them against the broader historical and political background of early 19th century history. I also do not intend to discuss issues of colonialism or Orientalism which one could easily address with regard to the not always undisputed methods of the scientists' activities in Central Asia - a region which did not belong, not even politically, to any of the parties involved. These debates I have to leave to more competent historians of the modern period.

Instead, I want to introduce some new source material from the Berlin archive of materials concerning the expeditions of German scholars to Eastern Turkestan ("Turfan-Akten") 5 . The archaeological exploration of Central Asia was from its very beginning a cooperative enterprise. The material introduced in this paper can help illustrate some of the aspects of this international collaboration and - in particular - the relationship between Russian and German scholars. It will show, how different strategies of argumentation were used for defending academic positions and claiming rights of academic exclusiveness and priority. Most of the material concerns a conflict between German and Russian scholars which became a kind of touchstone for the cooperative approach. Moreover - as recent publications show - this dispute is still today a matter of controversy and continues to complicate the present-day relations between scholars working on Central Asian material.

May the material presented here also help clarify some of the positions which caused the recent controversial discussions.

4. See the International Dunhuang Project website which coordinates the work of the various national projects and intends to provide a comprehensive database of the material collected in Xinjiang and kept now in different institutions world-wide (<http://idp.bl.uk/>, accessed 03.06.2014).

5. It is a pleasant duty to express my gratitude to the Museum für Asiatische Kunst, Staatliche Museen Preussischer Kulturbesitz, Berlin which gave permission to publish the material from the Turfan-Akten. I am especially grateful to my friend and colleague Caren Dreyer (Berlin), who guided me through the Turfan-Akten. Without her assistance and our numerous discussions, the current article would not have been possible. 
1. The question of priority and the "International Association for the archaeological and linguistic exploration of Central and East Asia"

It is generally acknowledged that the archaeological exploration of Eastern Turkestan was initiated by the expedition of Dmitrii Aleksandrovich Klementz (1847-1914). Based on the results of previous explorations ${ }^{6}$ - mainly under the auspices of the Russian Geographical Society - the Russian Academy of Sciences decided to organise an expedition exclusively devoted to the archaeological remains of Eastern Turkestan. This expedition took place in 1898. Klementz visited the oasis of Turfan and returned with a huge amount of information regarding the archaeological remains of this site and their enormous potential for further research ${ }^{7}$.

The Russian academician Friedrich Wilhelm Radloff (1837-1918) presented the results of this first intensive archaeological exploration of a Central Asian site at the 12th International Congress of Orientalists in Rome in 1899. Excited by the discoveries and huge opportunities a further exploration of this region would promise, the scholars decided to found an "International Association for the archaeological and linguistic exploration of Central and East Asia". The proposal for this foundation was made by Radloff who was later elected to act as the association's president ${ }^{8}$.

Klementz' information about artefacts and manuscripts from Turfan was not the only one that had reached the academic community. In 1890, Lieutenant Bower had purchased in Eastern Turkestan (Kucha) a rather large manuscript written on birch-bark. This manuscript was given to the Asiatic Society of Bengal in Kolkata. From there, it finally reached August Rudolf Hoernle (1841-1918), who was at that time

6. The early history of Russian scientific activities in Eastern Turkestan is subsumed by I. F. Popova, "Russian Expeditions to Central Asia at the Turn of the 20th Century”. For additional survey papers, see B. A. Litvinskii, A. P. Terent'ev-Katanskii, "Istoriia izucheniia", and C. Dreyer, "Russian Archaeological Explorations in Chinese Turkestan on the Turn of the 19th Century".

7. I. F. Popova, "Russian Expeditions to Central Asia at the Turn of the 20th Century", p. 28.

8. A commented extract of the Proceedings of the 12th International Congress of Orientalists is available in L. Genovese, Proceedings (Extract) of XII International Congress of Orientalists. 
Secretary of the Asiatic Society. Hoernle succeeded in deciphering and translating the manuscript (1893-1897), which he dated to the Gupta period, i.e. the 4th century AD. The manuscript is in fact a collection of seven different manuscripts, which contain medical Sanskrit texts and Buddhist texts such as the Mahāmàyürividyārājñ̄i ${ }^{9}$. The presumably old age of the manuscript ${ }^{10}$ and the interesting character of the texts motivated Hoernle to ask the British diplomats to buy more manuscripts. At the same time, manuscripts acquired by Russian diplomats based in Kashgar or Urumchi (N. F. Petrovskii, V. S. Kolokolov, S. V. Sokov, N. N. Krotkov) reached the Russian capital and were studied there by Russian scholars.

Thus the "run for manuscripts" had already begun when the Russians presented the material of Klementz' expedition in Rome and tried to convince their colleagues to carry out the exploration of Central Asia on a joint and cooperative basis. As Frances Wood in her book The Silk Road. Two Thousand Years in the Heart of Asia evaluated:

Hoernle [...] combined Great Game politics with “epigraphical exploration" in a report in his "Collection of Antiquities from Central Asia". "It was the discovery of the Bower and the Weber manuscripts that drew my attention to Eastern Turkestan as a promising field for epigraphical exploration. My hopes regarding the archaeological possibilities of that country were confirmed by what I heard about the success of the Russians, whose Political Agents were said to actively collect manuscripts and other antiquities for St Petersburg. Accordingly on the $1^{\text {st }}$ June, 1893, I wrote to [...] the Home Secretary of the Government of India, suggesting that the Government might send instructions to their Political Agents in different parts of Central Asia, to make enquiries and secure such specimens as they may be able to obtain "[...]. His desire to develop and expand the collection was to provide an impetus to the expeditions of one of the greatest explorersarchaeologists and collectors of Silk Road antiquities, Sir Marc Aurel Stein ${ }^{11}$.

9. The manuscript was published by R. A. F. Hoernle in three volumes between 1893 and 1912.

Io. As further palaeographical research showed, Hoernle's evaluation (4th century) was not correct. According to Lore Sander the "Bower manuscript" can be dated to the 6th century AD (L. Sander, "Origin and Date of the Bower Manuscript, a New Approach").

II. F. Wood, The Silk Road, p. 192 sq. 
With Aurel Stein's (1862-1943) expeditions (1900-1901, 1906-1908, 1913-1916, 1930-1931) a mighty and influential partner and competitor entered the scene. Contrary to the Germans and Russians - and later the French -, Stein as well as Hoernle never attempted to participate in the envisaged collaboration between the Silk Road explorers ${ }^{12}$.

Interestingly, Hoernle considered his decipherment and evaluation of the "Bower manuscript" to be the starting point for further discoveries. Usually the Russians claimed this position for themselves. Hoernle's point of view, thus, set the framework for further rival relationships ${ }^{13}$.

At the following 13th International Congress of Orientalists, which was held in Hamburg in 1902, the charter of the "International Association" was approved. According to this statute the association's headquarter was located to Saint Petersburg. Its affairs were mainly run by the "Russian Committee for the exploration of Central and East Asia” ${ }^{14}$.

Subsequently, a number of financially independent national committees were founded. These were supposed to coordinate their scientific activities in collaboration with the Russian headquarters. The statutes of these committees were published in the organs of the Russian committee Izvestiia Russkogo komiteta dlia izucheniia Srednei i Vostochnoi Azii $v$ istoricheskom, arkheologicheskom i lingvisticheskom otnoshenii [Transactions of the Russian Committee for the historical, archaeological and linguistic exploration of Central and East Asia] : 1903 - Russia,

I2. Stein maintained a rather collegial attitude. In 1901, he even visited Grünwedel in Berlin and "later took credit for giving impetus to Grünwedel's expedition and the subsequent German government grant" (S. Whitfield, "Scholarly Respect in an Age of Political Rivalry”, p. 212, fn. 21).

I3. In his preface to his edition, Hoernle remarked that "the discovery of the Bower manuscript and its publication in Calcutta started the whole modern movement of the archaeological exploration of Eastern Turkestan” (R. A. F. Hoernle, The Bower Manuscript, p. II).

I4. See I. F. Popova, "Russian Expeditions to Central Asia at the Turn of the 20th Century", p. 30 ; C. Dreyer, "Russian Archaeological Explorations in Chinese Turkestan on the Turn of the 19th Century", p. 66. The history and activities of this committee are subject of a special study by N. N. Nazirova, Tsentral'naia Aziia v dorevoliutsionnom otechestvennom vostokovedenii. 
1905 - Hungary, 1906 - France, 1907 - Italy. The statute of the German committee, which was founded in 1903, remained unpublished ${ }^{15}$.

It seems evident that by founding this association the Russians not only tried to coordinate the international activities in the exploration of Central Asia, but also to defend their priority in this field. Given the lasting history of Russian contacts with, and research on, Central Asia, it is not surprising that Russia exerted a sort of privilege or dominance in the further scientific exploration of that area.

This supposed predominance was also explicitly expressed by Russian scholars. For instance, in 1900, Nikolai I. Veselovskii (1848-1918), Dmitrii A. Klementz and the Russian Indologist Sergei F. Oldenburg (1863-1934) submitted a proposal to the Eastern department of the Russian Archaeological Society. They asked for support to go on a Russian expedition to Eastern Turkestan. Referring to Klementz' 1898 expedition, the applicants highlighted the work done by Russian researchers that "exceeds by far all that has been done in this field by foreigners". At the same time, they announced a "right of priority" in the exploration of these areas ${ }^{16}$. Some years later, the Russian Committee addressed a letter to the Ministry of Foreign Affairs complaining that the lack of financial support:

[...] have had an adverse effect on the Committee's projects in Eastern Turkestan, first by dramatically slowing down their progress and then by bringing them to a halt altogether, a situation that foreigners, i.e. the Germans and the French, were quick to benefit from: they have sent huge expeditions following in our footsteps. Unless the Committee resumes its activity vigorously and without delay, the Russian scholars' work of many years in Eastern Turkestan is likely to be completely wasted ${ }^{17}$.

It can be suggested that this attitude, which is also based on a growing Russian nationalism, constituted one of the barriers for the intended

I5. M. D. Bukharin, "Novye dokumenty k istorii izucheniia Vostochnogo Turkestana".

16. Quoted from B. A. Litvinskii, A. P. Terent'ev-Katanskii, "Istoriia izucheniia”, p. 29; cf. also I. F. Popova, "Russian Expeditions to Central Asia at the Turn of the 20th Century”, p. 29.

17. Quoted from I. F. Popova, "Russian Expeditions to Central Asia at the Turn of the 20th Century", p. 31 sq. 
international collaborations. As already mentioned, the British refused to be involved in the activities of the "International Association". After the Oriental Congress in 1902, Radloff had sent the British explorer Aurel Stein an official invitation to become member of the Russian Committee. He had also asked about the possibility to found a British National Committee. Stein had forwarded this request to Rudolf Hoernle. Hoernle, however, who had been both Secretary of the influential Asiatic Society in Bengal and founding member of the association in Rome, suspected that the Russians would exclude him from future work. Indeed, his name had been omitted from the documents presented in Hamburg ${ }^{18}$. Moreover, as Hoernle wrote, "the international committee are (sic!) simply advisory to the Central Committee which is exclusively Russian. This Russian Central Committee is practically a section of the Russian Foreign Office" 19. Thus, Hoernle suspected a political agenda behind the activities of the Russian Committee - a suspicion corroborated by the facts that firstly, part of the Committee's members consisted of state employees, and secondly, the Russian Ministry of Foreign Affairs oversaw financing of the national committee and its activities ${ }^{20}$.

While the British were reluctant to accommodate a leading role of the Russians in the coordination of the scientific exploration of Central Asia due to personal and political considerations, the Germans used their traditionally good contacts with Russia for their own academic interests. Already in 1899, on their way to the Congress of Orientalists in Rome, the Russians Klementz, Radloff and the Iranist Carl Gustav Heinrich Salemann (1849-1916) had visited the German scholar Albert Grünwedel (1856-1935) in Berlin to provide a short report on their discoveries in Turfan ${ }^{21}$. At that time, Albert Grünwedel was assistant director at the Ethnological Museum in Berlin and a specialist in Buddhist Art. It seems that both parties had even considered a common expedition. In a note dated the 26th September 1899, Grünwedel reports about the visit of Radloff and Salemann. They had brought specimens of cave

18. S. Whitfield, "Scholarly Respect in an Age of Political Rivalry", p. 212 sq.

19. Quoted from S. Whitfield, "Scholarly Respect in an Age of Political Rivalry", p. 213.

20. Cf. I. F. Popova, "Russian Expeditions to Central Asia at the Turn of the 20th Century", p. 31.

2I. L. Genovese, Proceedings (Extract) of XII International Congress of Orientalists, Rome, October 1899, p. 4. 
paintings and manuscripts to Berlin which they wanted to present to the Orientalists' Congress in Rome. According to Grünwedel, the Russians inquired about the possibility of a Prussian participation in a planned expedition by the Russian Academy (Appendix no 1).

The attempt to organise a joint expedition is mainly connected with the person of Prince Esper E. Ukhtomskii (1861-1921). Grünwedel was acquainted with Ukhtomskii and had studied his collection of Mongolian and Tibetan Buddhist objects. A catalogue of this collection was published in $1900^{22}$. It seems that Ukhtomskii planned a joint Russian-German expedition. According to Werner Sundermann, who studied the concerning material of the Turfan-Akten:

Ukhtomskiy failed to inform the Russian authorities and the imperial court in particular about his plans, and since this was done by the German embassy, Ukhtomskiy was accused by his adversaries of trying to plant foreign spies in an area of Russian interest. So the idea of a joint Russian-German expedition had to be given up, and Grünwedel made preparations for his own expedition, morally supported by his Russian colleagues in St. Petersburg who were also helpful in providing Russian passports ${ }^{23}$.

Thus the idea of a Russian participation never materialized and Grünwedel immediately began to plan a first German expedition which took finally place in 1902-1903. This expedition was mainly financed by private sources and yielded an enormous amount of results. Due to its great success it was soon decided to organize a second expedition. It was led by the scholar Albert von Lecoq (1860-1930) and took place between November 1904 and August 1905.

In 1903 the Germans had founded their own National Committee ("Turfankomitee"), which in the following years coordinated the activities of the German expeditions and which was one of the main channels

22. A. Grünwedel, Mythologie des Buddhismus in Tibet und der Mongolei; cf. also C. Trautmann-Waller, "Ot iskusstva Gandkhary k nemetskim ekspeditsiiam 19021914 gg. na Velikom shelkovom puti”, p. 165.

23. W. Sundermann, "Turfan Expeditions”. According to C. Dreyer, Ukhtomskii even "had to ask Grünwedel in a letter for an attest from the German Foreign Ministery that these plans had never existed (letter dated November 1901)" (C. Dreyer, "Russian Archaeological Explorations in Chinese Turkestan on the Turn of the 19th Century”, p. 66, fn. 18). 
of direct official contact between the Russian and German scholars. While applying in February 1904 for financial support for this second expedition, this committee had to argue in front of the Prussian Ministry for its new project. The Turfan-Akten contains a copy of this application (Appendix n ${ }^{\circ}$ 2) ${ }^{24}$.

Two points can be highlighted, which the German academics considered worthy of mentioning in their application:

1. The evaluation of German oriental studies as a kind of compensation for the colonial activities of countries like England;

2. The challenge to preserve Germany's important role in this field which is threatened by its limited access to the original sources.

Moreover, the document mentions the good relations with the Russians and the collegial support they provide. The document also notes that these good relations are threatened by growing nationalism in Russia.

It is obvious that the German scholars try to provide in their application arguments which are in accordance with the nationalist attitude of the German government and which would induce the ministry to approve their application. These colonial and nationalist arguments seem to be brought forward ad hoc and hardly reflect the motivation of the scholars. But the document helps to understand the lines of argumentation and the self-representation of oriental studies within the political context of pre-war Germany.

\section{The Russians and the Germans: the question of exclusiveness}

Without doubt, the good relations between the Russian and German scholars, especially between the two leading figures Albert Grünwedel and Sergei Oldenburg, facilitated successful activities across the four German expeditions to Eastern Turkestan (between 1902 and 1914). Yet, such collaborative approaches, regularly expressed explicitly by both parties, are questioned by decisions taken and goals pursued on each side pointing to a rather selfish agenda. To understand German and Russian positions, it has to be remembered that the Russian scholars initially failed in obtaining financial support for their own archaeological

24. The sketch of the application is also found among the Turfan-Akten (TA 920931). 
expedition to Central Asia. Despite the arguments brought forward by Veselovskii, Klementz and Oldenburg in 1900 (see above) ${ }^{25}$, the Ministry of Finances refused to finance a Russian expedition due to the lack of money ${ }^{26}$. The first archaeological expedition of the Russian Committee to Eastern Turkestan only took place in 1905-1907 under the guidance of Mikhail M. Berezovskii (1848-1912). The way Russian scholars perceived this development is clearly expressed by Sergei Oldenburg who wrote in 1917:

Russian scholars had also this time - as it happened and happens not rarely - to stand back from a successful enterprise they had started and which went over into the hands of foreigners, first of all of Germans, of scholars, who got in their country money for an expedition ${ }^{27}$.

It is obvious that the Russian scholars had to achieve their academic goals via direct and indirect participation in activities by foreigners. Coordinating these activities, the Russians secured their influence over the work done by these foreign expeditions. Of course, that way, they also remained informed about plans and major results gathered during these expeditions ${ }^{28}$.

While the Russians tried to "keep a foothold in the door", the Germans seemed to pursue a different goal. For the latter, the coordination offered by the Russians was an important way of securing a certain exclusiveness with regard to accessing particular archaeological sites and

25. Such an expedition had already been proposed in 1899 by the VII (Central Asian) Session at the 12th International Congress of Orientalists: "The government of Russia and the relevant institutions of learning to organise and finance an expedition to Central Asia to further the knowledge acquired by the explorations already undertaken by Klementz" (L. Genovese, Proceedings (Extract) of XII International Congress of Orientalists, Rome, October 1899, p. 13).

26. I. F. Popova, "Russian Expeditions to Central Asia at the Turn of the 20th Century”, p. 29; B. A. Litvinskii, A. P. Terent'ev-Katanskii, “Istoriia izucheniia”, p. 29.

27. Quoted from B. A. Litvinskii, A. P. Terent'ev-Katanskii, "Istoriia izucheniia”, p. 30 .

28. Thus N. N. Nazirova, who investigated the documents of the Russian Committee, evaluates its activities as follows: "Supporting the expeditions of foreign scholars, the Russian committee also defended the priority of Russian academics, while fighting against the attempts of some foreign committees to monopolize one or another work, e.g., in some regions of Eastern Turkestan" (N. N. Nazirova, Tsentral'naia Aziia $v$ dorevoliutsionnom otechestvennom vostokovedenii, p. 30). 
areas. This German approach is still being controversially discussed and complicates the relations between Russian and German authorities in the international collaboration on Central Asian manuscripts and artefacts. Several authors refer to a kind of pact or agreement between the Russian and the German side, where the "zones of interest" of both parties in the archaeological exploration and exploitation of Eastern Turkestan had been defined.

Thus Susan Whitfield writes:

There was some dispute as the Germans held that Grünwedel had made a pact with the Russians concerning spheres of work, that the Germans could excavate around Turfan and the Russians around Kucha. When the Germans arrived at Urumqi they found that the Russians had already been to Turfan and, feeling the pact had been broken, set off themselves to Kucha. After this there was no pretence at reserving sites by gentleman's agreement ... ${ }^{29}$

According to Whitfield, the Russians broke this assumed "agreement" during the second and third German expedition in 1904-1906. Because of this violation the Germans considered the agreement as invalid.

A different picture was presented by Irina Popova. She dated the violation of the "agreement" to an earlier point in time, i.e. to the first German expedition after the Hamburg Orientalists' Congress in 19021903. Popova, director of the Saint Petersburg Institute of Oriental Studies of the Russian Academy of Sciences, writes:

National committees set up [...] in many countries agreed on dividing Eastern Turkestan territories for investigation by Europeans. In spite of this, A. Grünwedel's expedition, organized immediately following the Congress, violated the agreement ${ }^{30}$.

The following remarks will show that Popova is definitely wrong in her dating. But the picture presented by Whitfield is also only half the story. To understand the chronology of this controversy and its genesis it is important to go back to the original documents which are kept in the archives of the Russian and German institutions.

29. S. Whitfield, "Scholarly Respect in an Age of Political Rivalry", p. 214.

30. I. F. Popova, "Russian Expeditions to Central Asia at the Turn of the 20th Century”, p. 30. 
The controversial debate seems particularly fostered through the absence of an official document proving any such agreement. In any case, the establishment of such an arrangement was not part of the statutes of the International Association nor of the national committees, as Popova's remark might suggest.

As far as I am aware of, there exist only a few letters between German and Russian scholars which refer to such an agreement, although in sometimes contradictory terms.

Recently, Mikhail Bukharin (2014) edited and studied the respective letters kept in the archive of the Russian Academy of Sciences. According to these letters, an agreement on the "division of Eastern Turkestan" was formulated by Grünwedel in preparation of the second German expedition in 1904. A letter by Grünwedel which is now kept in the Russian archives shows that the Germans had applied for the permission to explore sites in the Turfan area in August 1904 (letter Grünwedel - Radloff, 22nd August 1904 ${ }^{31}$ ). The reaction of the Russian side to this application remains unclear.

Most of the remaining letters kept in the Russian archive concern the complaints of M. M. Berezovskii, the leader of the 1905-1908's Russian expedition. Berezovskii started to explore Kucha in spring 1906. At that time the third German Turfan expedition (December 1905 - April 1907) was also active in this area. Berezovskii blamed the Germans for having broken the agreement by entering the Kucha area that had been reserved for the Russian expedition. From the letters kept in the Russian archives it becomes obvious that the initial agreement concluded in 1904 was modified by additional arrangements concerning the area around Kucha. While Berezovskii stated that these additional arrangements concerned Kumtura only ${ }^{32}$, Grünwedel referred to an oral agreement with Wilhelm Radloff, the head of the Russian committee. According to Grünwedel, the latter allowed the Germans to extend their exploration into the entire Kucha area ${ }^{33}$.

3I. M. D. Bukharin, “Novye dokumenty k istorii izucheniia Vostochnogo Turkestana", $\mathrm{n}^{\circ} 4$.

32. Letter Berezovskii - Grünwedel, the 23th May 1906: M. D. Bukharin, "Novye dokumenty $\mathrm{k}$ istorii izucheniia Vostochnogo Turkestana", $\mathrm{n}^{\circ} 6$.

33. M. D. Bukharin, "Novye dokumenty k istorii izucheniia Vostochnogo Turkestana", no 8 . 
In the following, I am presenting the documents from the Berlin Turfan-Akten, which concern this debate. These additional materials can help to contextualise the documents of the Russian archives published by Bukharin and provide the German perspective which is necessary to evaluate the validity of the arguments brought forward by both sides.

The agreement contents between the Russian and the German sides are referred to in several documents from the Turfan-Akten. In particular, Grünwedel's report on his journey to Saint Petersburg in autumn 1904 describes the contents of the agreement (Appendix $n^{\circ} 3$ ). He writes that the German committee had got the permission to explore the entire valley of Turfan. Moreover, Grünwedel mentions the Russian painter Samuil M. Dudin (1863-1929) who was obviously meant to accompany the German expedition for preparing copies and drawings of the frescos.

In a similar way, Grünwedel described this agreement in a note which is part of a circular of the German Committee dated the 27th February 1905 (Appendix n ${ }^{\circ}$ ). Again he stresses that Turfan "and the environment of Bugur and Kurla" were appointed to the German expeditions while the Russians were meant to explore the oasis of Kucha which was far away from Turfan. According to Grünwedel, Radloff said to him in late autumn 1904: "Turfan we will give up." This circular was meant to prepare a reaction from the German side to a letter from the Russian Committee.

This letter as well as most of the remaining documents from the Turfan-Akten concerns an episode in late 1904, an episode that predates the later dispute between Berezovskii and the Germans. Then, the second Prussian Turfan expedition under the guidance of Albert von Lecoq explored the area around Turfan. To this point in time, one can safely locate the beginning of the dispute between the German and the Russian Committee concerning the assumed division of Eastern Turkestan. During his work in Turfan, Albert von Lecoq met the Russian A. I. Kokhanovskii, who was a doctor and served as the second consul in Urumchi. Kokhanovskii was interested in archaeological issues and also collected manuscripts. Lecoq perceived these activities as violations of the mutual agreement and expressed his concerns to Kokhanovskii.

According to a letter by Klementz to Oldenburg dated the 9th December 1904, Kokhanovskii's activities in Turfan followed 
the advice of Klementz, who had "recommended him to deal with the collection of information about the antiquities of Turfan, to take photographs and to collect frescos and manuscripts" 34 . In this letter, Klementz admits that he had not informed the Russian Committee about this issue. He complained about Lecoq's attitude and asserted that he is unaware of an agreement between the Russian and the German committee. He also denied the meaningfulness of such an agreement, even if it would exist.

In February 1905 the German Committee received a copy of a letter, which the Russian National Committee had sent to the Russian consulate in Urumchi. It was signed by its president Radloff and its secretary Sternberg. The letter refers to the "agreement" and clarifies the Russian position. A German translation of this letter is part of the Turfan-Akten (Appendix $\mathrm{n}^{\mathrm{O}}$ 5). The letter is mainly devoted to the controversy between Kokhanovskii and Lecoq. It quotes Lecoq's argument, that the "area has already been divided" and that "all locations between Turfan and Kucha have to be considered as sphere of activity of the German expedition". Radloff refuses this argumentation and argues that this agreement would only concern expeditions delegated by both sides, but not private persons who are pursuing their own personal research interests.

Although there is an obvious discrepancy with regard to the interpretation of the agreement's impact, this letter clearly shows that the Russian Committee admitted the existence of this agreement, but tried to limit its impact to the activities of academic expeditions.

The president of the German Committee, the Indologist Richard Pischel (1849-1908), replied in a letter to the Russian Committee dated from the 23rd March 1905 (Appendix no 6). Reacting on Radloff's letter, Pischel tried to extend the agreement's impact by stating that Kokhanovskii had to be regarded as a person who is under the direct influence of the Russian Committee. He described his activities which included the purchase of paper (manuscripts?) and even excavations. Moreover, he used his letter to specify the zones of Lecoq's activities, which according to him had been reported to the Russian Committee. According to Pischel, these zones are defined as follows: "Turfan,

34. S. O'ldenburg, Etiudy o liudiakh nauki, p. 232 sq. The letter is partially re-edited, with the correct date, by M. D. Bukharin, "Novye dokumenty k istorii izucheniia Vostochnogo Turkestana”, nº 2 . 
Idykutšari, the valley of Sengimauz, the valley of Murtuk, the cave north of the Chinese town between Kurutka, Baghra, Buturuk, the oasis of Hami, and the environment of Kurla". It is interesting to note that these zones completely correspond to the areas indicated by Grünwedel in his letter to Radloff from the 22nd August 1904, which is kept today in the Russian archives ${ }^{35}$. In this letter, Grünwedel informs Radloff explicitly on behalf of the (German) Committee, that in autumn 1904 an expedition by the Prussian Ministry of Culture will take place. As participants, the letter mentions A. von Lecoq and the museum's technician Bartus. Moreover, Grünwedel asks to assign to the German expedition the following sites:

1. Idikutshari, the ruins to the north of the Chinese town of Turfan, between Buturuk and Bagra, the valley of Sengimauz and the Murtuk river;

2. the oasis Hami;

3. the environs of Kurla, in particular the ruins between Karashahr, Bugur and Singim (Sangir).

It seems obvious that Pischel referred to, in his reply to the Russian Committee, the same list and letter. According to Pischel, the Russian Committee had never raised any objections to this distribution of sites. This might indicate that there had never been written any official response to Grünwedel's request of August 1904 and that the silence of the Russian Committee was interpreted by the Germans as a sign of consent.

It is surprising to observe that in its letter of reply dated from the 4th April 1905, the Russian Committee denied the receipt of such a German request (Appendix no 7 ). Of note, Grünwedel's letter containing this list is kept today in the Russian archives. One can therefore infer that it had reached its recipient. Why its receipt was denied and why it had not been answered, is beyond the information which can be drawn from the documents studied here. In this letter of reply, Radloff on behalf of the Russian committee refers to an oral agreement of a different content. He says that the Russian academic Salemann had informed the German side on behalf of the Russian Committee about the possibility of including Idikutshari in the activities of the German expedition.

35. The letter was published by M. D. Bukharin, "Novye dokumenty k istorii izucheniia Vostochnogo Turkestana”, no 4 . 
Moreover, Radloff remarks that the Russian Committee is also content to leave the valleys of Sengimauz and Murtuk to the Germans. "With this single exception, we are not aware of any other arrangements or agreements", the letter stresses. Moreover, the letter again points to the Russian attitude that any agreement would only concern expeditions undertaken by both sides and had no impact on the activities of other independent researchers such as Kokhanovskii, who "had never had any relation to the Russian Committee". It is interesting to note that the letter refers to the priority rights of Russian scholars thus returning to the previous nationalistic argumentation. Radloff stresses that:

Russian science can claim an undisputable right of priority in these areas: only the discoveries of the expeditions which were equipped by our Geographical Society and in particular the results of the journey by Mr. Klementz on behalf of our academy made the successful research of Professor Grünwedel possible.

The person who instigated this illuminating controversy, Kokhanovskii, wrote to Albert von Lecoq in May 1905. The P.S. of this letter is kept in the Turfan-Akten (Appendix ${ }^{\circ} 8$ ). It was added to the files by Grünwedel as a kind of proof for the agreement's violation. Grünwedel made the following note on the file: "Letter of Dr. Kochanowskii containing the request of the Petersburg academics to work on the area assigned to us for their museums, etc.” (TA 3269). In this P.S., Kokhanovskii reacts on the German accusation that he would destroy archaeological sites and stresses that any kind of demolition has to be ascribed to his predecessors. Again Kokhanovskii refers to the Russian priority rights. According to him, the Russians "have most rights, because they came first to this district". He mentions Ioann-Albert Regel (1845-1909), D. A. Klementz and Grigorii E. Grumm-Grzhimailo (1816-1936) as examples. Moreover, he points to the necessity in working for Russian science and museums.

As Grünwedel's note already shows, the German side interpreted Kokhanovskii's activities in Turfan as work done on behalf of the Russian Committee and hence a violation of the assumed agreement. The same attitude is expressed in a note by Lecoq dated the 13th January 1909, who also handed over a copy of this P.S. to the Turfan-Akten (Appendix n 9). 
Both letters, that of Radloff and that of Kokhanovskii, also show how nationalistic arguments entered the debate. Assumed rights of priority became decisive for the definition of the status of both partners. It seems that the initial trustful atmosphere ceased to prevail in the course of the year 1904. The increasing stress of priority rights is accompanied by the progressive modification, denial and misinterpretation of former agreements. It is presently difficult to evaluate the reasons for this development, but it cannot be excluded that personal differences which resulted in a severe loss of trust played a major role in this process ${ }^{36}$. On the other hand, the preparation of the first Russian expedition had started. In 1905, the zoologist M. M. Berezovskii was sent by the Russian Committee to Kucha ${ }^{37}$. Thus it is equally possible that the Russians now tried to reserve certain promising areas for their own explorations.

In the Kokhanovskii episode between 1904-1905, the Germans blamed the Russians of violating the agreement. In the subsequent controversy between Berezovskii and the Germans, the Russian side raised this accusation. Berezovskii considered the activities of Lecoq in KirishSimsin, a site near Kucha, as violating the contract. He wrote a protest note to Grünwedel. Here he refers to an agreement between the Russian and the German committee according to which the Germans would investigate the Turfan district while the Russians were in charge of the Kucha area. He admits that the Russian Committee had agreed on Grünwedel's proposal to extend the Germans' activities to Kumtura, a site in the Kucha oasis. But they had never been given the permission to explore other parts of Kucha, and in particular the Kirish site, where the Russians were supposed to work ${ }^{38}$.

According to Grünwedel's reply, however, Radloff gave him the oral permission to work in the "surroundings of the city of Kucha" which according to him included sites like Kyzyl and Kirish. Grünwedel writes

36. Thus C. Dreyer says: "Le Coq and F. W. K. Müller had scientific objections against V. V. Radlov and his work with the Turkish manuscripts" (C. Dreyer, "Russian Archaeological Explorations in Chinese Turkestan on the Turn of the 19th Century", p. 67, fn. 19).

37. M. I. Vorobyeva-Desyatovskaya, “M. M. Berezovsky's Expedition to Kucha (1905-1908)".

38. May 1906, M. D. Bukharin, "Novye dokumenty k istorii izucheniia Vostochnogo Turkestana", no 7 . 
that Radloff had allowed him to remove frescos and had asked him for photographs in the case that Uighur manuscripts were discovered ${ }^{39}$.

As far as one can judge, it was this "misinterpretation" of Radloff's approval which caused the controversy between Berezovskii and Grünwedel.

The materials from the Russian archive contain no further information about this issue.

But there is a letter from Sergei Oldenburg to Albert Grünwedel dated the 26th August 1905 which might shed some light on the position of Kucha in the Russo-German agreement (Appendix $\left.n^{\circ} 10\right)$. In this letter of August 1905, i.e. 9 months before Berezovskii came to Kucha, Oldenburg writes:

[...] I had to discuss this issue with Klementz, Grigoriev and Berezovskij. Yesterday the gentlemen were with me and we all agreed that if you would like to explore this place (i.e. Kucha) and would like to take the frescos and other antiquities for your museum we would be much in favour of this, because nobody will be able to do it the way you do and for science it is irrelevant where the pieces are kept. In this case, Berezovskij will explore other areas.

It therefore seems that the Russian side was at least temporarily inclined to abandon its claims for the Kucha area and Grünwedel's attitude can be easily understood against the background of this former discussion. However, whether Radloff's assumed oral permission was based on this agreement mentioned by Oldenburg must remain open.

\section{Conclusion}

The political interests of the Russians and the British in Central Asia promoted the scientific exploration of this area considerably. Orientalists became involved in this exploration at a rather later point in time. While the British Orientalists with Hoernle and Stein followed a policy of strictly independent activities, the Russians decided to opt for an international cooperation. One of their main partners in this cooperation

39. May 21, 1906, M. D. Bukharin, "Novye dokumenty k istorii izucheniia Vostochnogo Turkestana", no 8 . 
was Germany ${ }^{40}$. The reasons for this option are likely at least twofold. Firstly, the Russians tried to gain ground against the growing British influence profiting from the academic experience and material support of their international partners. Secondly, the missing financial support of the Russian government forced the Russians to directly or indirectly participate in the activities of foreign missions. Both these reasons were, however, mainly based on a latent statement of a Russian right of priority in the exploration of Eastern Turkestan. This right of priority explained by the former achievements of Russian expeditions and researchers were met on the German side by the strong desire for direct and exclusive access to original sources in order to preserve the leading role of German Oriental Studies.

In the documents and letters presented here, we could find repeated references to both of these attitudes. Nationalist priority arguments and aspiration for exclusiveness promoted an atmosphere of mutual mistrust between some of the involved scholars. The dispute about the actual existence, contents and interpretation of an assumed agreement between both parties illustrates the increasing degree of this mistrust - a mistrust which finally prevented the realisation of a joint and collaborative exploration of Eastern Turkestan.

The diverging evaluation of these events in recent academic literature - as found in the works of British or Russian scholars - show that still today not all traces of this mutual mistrust are overcome.

Ingo STRAUCH

Université de Lausanne

40. There was also a close cooperation with French colleagues - especially with the Sinologist Paul Pelliot (1878-1945) - who organised their first expedition to Eastern Turkestan (Kucha, Dunhuang) in 1906. The cooperation between the Russian and the French side is well documented in the correspondence between the French and Russian scholars published in 2004 by G. M. Bongard-Levin, R. Lardinois and A. A. Vigasin, Correspondances orientalistes entre Paris et Saint-Pétersbourg (1887-1935). 


\section{APPENDIX \\ DOCUMENTS FROM THE TURFAN-AKTEN}

No 1: TA 29, note by Grünwedel, 26.09.1899

Die Akademiker Prof. Dr. Radloff und Prof. Dr. Salemann aus Petersburg brachten gestern Proben der in Turfan gefundenen Höhlengemälde nach Berlin (ferner Handschriften und Druckproben, welche sie dem Congress in Rome vorlegen wollen. Sie legten nahe, ob eine Beteiligung an einer grösseren Expedition der Akademie seitens der preussischen Regierung möglich sei und wünschten im Notfalle eine wenigstens wissenschaftliche Unterstützung der Sache durch Hinweis auf die Bedeutung der ganzen Sache.

26. Sept. 99. Grünwedel

$N^{\circ}$ 2: TA 900-919, copy of an application letter to the Prussian Ministry, February 1904 (extract)

Die orientalischen Studien in Deutschland entsprangen an der Scheide des 18. Jahrhunderts idealen Bestrebungen, wie die damalige Zeit sie liebte, auf der Basis kosmopolitischer Ideen, deren beredtster Vertreter in Deutschland Herder war. Abgeschnitten vom direkten Zusammenhang mit dem Orient, war die Arbeit auf die Studierstube beschränkt, die Materialien lieferte das Ausland. Deutscher Fleiß widmete sich jenen wissenschaftlichen Betätigungen vom rein theoretischen Standpunkte mit der gründlichen Schulung, welche durch die Beschäftigung durch die Antike gewonnen wurde, während die ausländischen Mächte - in erster Linie England - mit der praktischen Seite, der Einrichtung und Nutzbarmachung seiner Kolonien, beschäftigt war: speziell in Indien hat der deutsche Name sich einen ehrenvollen Ruf gesichert.

Die Zeiten haben sich geändert. Zunächst ist die wissenschaftliche Fragestellung eine andere geworden. Die wichtigsten Seiten der indischen Altertumskunde müssen heute der ausgleichenden vermittelnden Stellung, der deutschen wissenschaftlichen Forschung entsprechend, diejenigen sein, welche Indien der Weltgeschichte eingliedern. 
Es ist dies die Zeit der indischen Kolonisation, welche Hinterindien, den malaiischen Archipel und Zentralasien mit Königsdynastien beschenkte, und Hand in Hand damit, der Missionstätigkeit der buddhistischen Mönche. Die von der Wissenschaft zunächst fassbaren Zeugen dieser denkwürdigsten Zeiten indischen Lebens bietet die Archaeologie mit ihren Nebengebieten: Epigraphik, Architekturgeschichte usw.

Die Zeiten haben sich auch in anderer Beziehung geändert. Es kann und darf die betrübende Tatsache nicht verschwiegen werden, dass Deutschland immer mehr in den Hintergrund gedrängt wird. Es findet dies darin seinen Ausdruck, dass uns durch Ausfuhrverbote das Material entzogen wird; wir sind also, wollen wir uns nicht mit Kleinigkeitkrämereien beschäftigen lassen, von den großen Aufgaben ausgeschlossen. Indien ist uns verschlossen, da England eifersüchtig darüber, daß nichts ausgeführt wird, seine frühere fördernde Thätigkeit, welche dem Deutschen lange zu Gebot stand, aufgegeben hat und lieber völlig unfähige Landeskinder anstellt als Deutsche mit genügenden Kenntnissen.

Die an uns herantretende Aufgabe ist die Folgende.

Im Ausgang der neunziger Jahre des vorigen Jahrhunderts brachten russische Reisende wie Roborovskij, Koznakof, Grum Grschmailo etc. überraschende Nachrichten über umfangreiche Ruinen in den Ländern südlich des Tien Shan Gebietes, Handschriftenfunde, Bronzen und andere Altertümer der merkwürdigsten Art, aus der Gegend von Kutscha wurden durch den Kaiserlich Russischen General-Konsul Petrovsky von Kaschgar aus an die Akademie gesandt, Dutreuil de Rhins fand höchst interessante indische Handschriften in derselben Gegend (Kutscha) und fast gleichzeitig entdeckte Sven Hedin auf einer Reise nach Tibet auf dem „Trümmerfelde “ (Takla Makan) im Sande der Wüste Städte und Tempel mit hochinteressanten Fresken. Man besann sich auf die Quellen über das Land und fand in der chinesischen Literatur genügenden Hinweis auf die Bedeutung des Gefundenen. Die Kaiserliche Akademie in S. Petersburg gab darauf sofort ihrem damals in der Mongolei befindlichen Reisenden Klementz den Auftrag, über Turfan zurückzureisen und authentisches Material mitzubringen. Dies geschah und die Ausbeute war eine so außerordentlich merkwürdige, daß die russischen Akademiker beschlossen, die Angelegenheit dem Orientalisten-Kongreß in Rom vorzulegen und eine gemeinsame internationale Aktion hervorzurufen, die das neugewonnene, ausgedehnte und vielversprechende Gebiet bewußt 
bearbeiten sollte. Dies waren die Vorgänge, welche die Berliner TurfanExpedition veranlaßten. Sie blieb im Connex mit den Russen und, wie mit Freuden bezeugt werden kann, hatte sich der energischsten Hilfe zu erfreuen. Ohne Verbindung mit der russischen Akademie sandte die Indische Regierung H. Stein nach der südlichen Seite des Gebietes, eine Expedition, welche glänzende Resultate brachte. Noch während der Reise der Berliner Expedition brachte Excellenz Radloff, Akademiker, Wirklicher Geheimer Staatsrat in S. Petersburg, bei Gelegenheit des Orientalisten-Kongresses in Hamburg, die Bildung von Lokalkomités in Anregung, welche im Zusammenhange mit dem in erster Linie beteiligten russischen Komité, im übrigen aber völlig selbständig, weitere Nachforschungen und Ausgrabungen in Ost-Turkestân betreiben sollten. Für Deutschland wurden gewählt die Professoren Pischel und Grünwedel in Berlin, Kuhn in München und Leumann in Strassburg i/E. Diesem Komité sind beigetreten die Herren:

Prof. Dr. Frhr. von Richthofen, Geheimer Regierungs-Rat,

Prof. Dr. Sachau, desgleichen,

Prof. Dr. Geldner,

Dr. F.W.K. Müller, Direktorial-Assistent bei den Königlichen Museen,

Prof. Dr. Foy,

Prof. Dr. Hartmann,

Prof. Dr. A. Forke,

Dr. O. Franke,

Prof. Dr. Wilhelm Schulze,

Prof. Eduard Meyer.

Das russische Komité hat über seine Tätigkeit bereits zwei Bulletins veröffentlicht, welche wir uns gestatten, hier beizufügen. Es wird seitens der Kaiserlich Russischen Akademie eine Expedition ausgerüstet, welche vom Staate reichlich mit Mitteln unterstützt worden ist. Auch in Frankreich, welches schon durch die Sendung des gelehrten Bonin sein Interesse bekundet hatte, ist das Komité bereits in Tätigkeit getreten.

Wir können mit Vergnügen darauf hinweisen, daß die Russen uns im Gegensatz zu den Engländern hilfreich zur Seite stehen, aber es ist nicht zu verkennen, daß auch hier nur eine günstige augenblickliche Lage sich bietet. Solang Gelehrte, wie Radloff und Sergius von Oldenburg entscheidend wirken können, - ist eine antideutsche Bewegung nicht zu befürchten. Wie weit im übrigen die in Deutschland stets wachsende 
Würdigung der nationalrussischen Gelehrsamkeit, welche in den letzten Jahrzehnten Glänzendes geleistet hat, genügen wird, den so vorteilhaften Bund zu bewahren und fremdenfeindliche Bewegungen nicht aufkommen zu lassen, ist eine andere Frage.

Unter diesen Umständen ist periculum in mora. Die Unterzeichneten halten es für eine nationale Ehrenpflicht, daß Deutschland nicht hinter anderen Ländern zurückbleibe und die gebotene Lage rechtzeitig und mit ausreichenden Mitteln ausnütze ... ${ }^{41}$

\section{No3: TA 1023-1026, report by Grünwedel, 15.12.1904 (extract)}

Es wurde mir nun mitgeteilt, dass dem Berliner Comité das ganze Thal von Turfan zur Exploration überlassen werden soll und dass der russische Maler Dudin, welcher schon einmal in Turfan war und die schönen Freskencopien hergestellt hat, welche wir im Austausch mit der russischen Akademie erworben haben, uns beigegeben werden soll für unsere Zwecke, wenn wir und er selbst es wünschen. Eine endgültige Abmachung mit Dudin ist indess nicht erfolgt.

No 4: TA 1050-1053, circular of the German Committee, 27.02.1905 (extract $=$ note by Grünwedel)

Zunächst muss ich bemerken, dass die von Turfan weit abliegende Oase von Kutscha überhaupt den Russen zugesagt war, - uns Turfan und die Umgebung von Bugur und Kurla. „Turfan geben wir auf," sagte R. zu mir im Spätherbst 1904.

$N^{\circ} 5:$ TA 5703, letter of the Russian Committee to the Imperial-Russian Committee (consulate) in Urumchi, 16.02.1905

Herr Klementz, Mitglied des Russischen Comité der Internationalen Association hat einen Brief von Dr. Kochanowski aus Urumtschi dem

4I. The document continues with a detailed description of the artifacts, which can be expected from an expedition, and a calculation of the costs. 
Russ. Comité übermittelt, in welchem er die Mitteilung macht, dass Dr. von Lecoq ihm erklärt habe, dass in der Internationalen Association für die Erforschung Central und Ostasiens die hiesige Gegend schon verteilt sei, dass alle Oertlichkeiten zwischen Turfan und Kutscha als Wirkungskreis der Deutschen Expedition anzusehen seien, und dass so lange sich die Deutsche Expedition hier aufhalte, weder eine andere Expedition noch einzelne Personen das Recht hätten, Ausgrabungen vorzunehmen oder sogar alte Funde käuflich zu erwerben. In Folge dessen ersuche ich Herrn Kochanowski zu benachrichtigen, dass die Uebereinkunft zwischen dem Deutschen und dem Russischen Comité der Internationalen Association nur die von den beiden Comités entsendeten Expeditionen betrifft und durchaus nicht andere Forscher verhindert ihre Untersuchungen dort vorzunehmen, wo sie es für nötig halten, selbst in den Wirkungskreisen die die beiden Comités für ihre Expeditionen bestimmt haben. Es ist natürlich erwünscht, dass solche Arbeiten in wissenschaftlicher Weise geführt werden mit der gehörigen Rücksicht auf die schon von Anderen in Angriff genommenen Arbeiten. Der Vorsitzende - W. Radloff

Der Secretär - L. Sternberg

No6: TA 1054-1055, letter by Pischel to the Russian Committee (copy), 21.03.1905

Auf das gefällige Schreiben vom 16. Februar beehrt sich der Unterzeichnende im Auftrage des Deutschen Komités ergebenst zu erwidern, dass die Abmachungen zwischen dem Deutschen und Russischen Komité sich naturgemäß nur auf die Arbeiten solcher Persönlichkeiten beziehen können, auf die das betreffende Komité einen Einfluss auszuüben imstande ist. Dass Herr Dr. Kochanowski zu diesen Persönlichkeiten gehört, glauben wir daraus schliessen zu dürfen, dass er sich mit Herrn Klementz in Verbindung gesetzt hat, der Mitglied des Russischen Komités ist. Nach einem Briefe des Herrn von Lecoq vom 11. Dezember 1904 ist Herr Dr. Kochanowski einen Tag nach dem Eintreffen der deutschen Expedition in Urumči dieser nachgeeilt, hat sie überholt und in Turfan Papier und dgl. aufzukaufen gesucht. Er hat ferner in Begleitung eines deutschen Uhrmachers dort Ausgrabungen gemacht, zweifellos in unwissenschaftlicher Weise, da 
Herr von Lecoq alles in trostlosem Zustand gefunden hat. Wir erinnern uns, dass wir dem Russ. Komité mitgeteilt haben, dass Herr von Lecoq den Auftrag erhalten hat, Turfan, Idykutšari, Tal von Sengimauz, Tal von Murtuk, Höhlen nördl. von der Chinesenstadt zwischen Kurutka, Baghra, Buturuk, die Oase von Hami, Umgebung von Kurla zu explorieren. Das Russ. Komité hat dagegen keine Einwände erhoben. Alle unsere Abmachungen, überhaupt jede Wirksamkeit der internationalen Assoziation würde vergeblich sein, wenn Privatpersonen störend eingreifen.

Wir ersuchen daher das Russ. Komité im Interesse der Wissenschaft auf Herrn Kochanowski seinen ganzen Einfluss dahin ausüben zu wollen, dass er seine Sammeltätigkeit in dieser Gegend einstellt.

Herr von Lecoq hat Abschrift dieses Schreibens erhalten.

gez. R. Pischel

An das Russische Komité der Intenationalen (sic!) Assoziation für die Erforschung Zentral- und Ostasiens in St. Petersburg

$N^{\circ} 7:$ TA 5708-5710 (copy = TA 1109-1112), letter of the Russian Committee to the German Committee, 14.04.1905

An das Deutsche Komité der Internationalen Association für die Erforschung Zentral und Ostasiens

Indem ich hiermit den Empfang Ihres gefälligen Schreibens vom 21. März bestätige, habe ich die Ehre Ihnen im Auftrage des Russischen Komités zu erwidern, dass dem Komité die in Ihrem Schreiben erwähnte Mitteilung, Herrn von Lecoq sei der Auftrag erteilt worden, „Turfan, Idykutšari, das Tal von Sengimauz, das Tal von Murtuk, die Höhlen nördlich von der Chinesenstadt zwischen Kurutka, Baghra, Buturuk, die Oase von Hami, die Umgebung von Kurla zu exploriren ", leider nicht zugegangen ist. Auf Grund einer vom Komité erhaltenen Vollmacht hat Herr Akademiker Salemann bei seinem Aufenthalt in Berlin Ihnen persönlich mitgeteilt, dass wir bereit sind die Erforschung von Idykutšari dem Deutschen Komité ganz zu überlassen; das Komité hat sich jetzt bereit erklärt in diesen Begriff auch das Tal von Sengimauz und das Tal von Murtuk einzuschliessen. Mit dieser einzigen Ausnahme sind uns keinerlei Verabredungen oder Abmachungen über diesen Gegenstand bekannt. Auf eine Abmachung, welche das ganze Gebiet von Kurla bis Hami für 
alle Zukunft aus unserem Wirkungskreis ausschliessen würde, könnten wir nicht eingehen, um so mehr, als die russische Wissenschaft in diesen Gebieten ein unbestreitbares Prioritätsrecht beanspruchen kann : erst durch die Entdeckungen der von unserer Geographischen Gesellschaft ausgerüsteten Expeditionen und besonders durch die Ergebnisse der im Auftrage unserer Akademie ausgeführten Reise des Herrn Klementz sind Herrn Professors Grünwedel erfolgreiche Forschungen möglich gemacht geworden. Gegen diese Expedition, wie gegen die jetzt in Turfan tätige Expedition des Deutschen Komités haben wir nicht nur keinen Einspruch erhoben, sondern auch beiden Unternehmen in allen Fällen, wo wir darum ersucht worden sind, unseren Beistand erwiesen; doch glauben wir damit keineswegs irgend welche ausschliesslichen Rechte einer Expedition anerkannt zu haben. Aus den Ergebnissen der bisher aufgeführten Forschungen glauben wir schliessen zu dürfen, dass die in den Gegenden um Turfan, Kurla und Hami allmählich zu Tage tretenden wissenschaftlichen Schätze noch manche Expedition beschäftigen werden, selbst wenn die Gelehrten der verschiedensten Nationen sich an diesen Arbeiten beteiligen wollten. Aus diesen Gründen können wir die Ansprüche des Herrn von Lecoq auf ein ausschliessliches Recht der Erforschung dieser Gegenden nicht als berechtigt anerkennen.

Herr Dr. Kochanowski hat zum Russischen Komité nie in irgend welchen Beziehungen gestanden. Vor seiner Abreise nach Urumtči als Arzt des Kaiserlich Russischen Konsulats daselbst hat er sich mit der ethnographischen Abteilung in dem zum Andenken an Kaiser Alexander III gestifteten Museum in Verbindung gesetzt und auf seinen Wunsch von Herrn Klementz, dem Leiter dieser Abteilung, Auskunft darüber erhalten, welche Dienste ein in Urumtči ständig wohnender gebildeter Mann dem Museum und der Wissenschaft überhaupt erweisen könnte. Bestimmte Aufträge, welche mit unseren dem Deutschen Komité bekannten, leider bisher nicht zur Ausführung gelangten Plänen zusammenfallen würden, hat Herr Klementz, Mitglied unseres Komités, welcher diese Pläne eifrig befürwortet hatte, uns über derartige Aufträge nie irgend etwas vorgelegt (sic!). - Die Statuten der Association und des Komités geben uns kein Recht Personen, welche der Association fern stehen, jede wissenschaftliche Tätigkeit in den betreffenden Gebieten zu untersagen; auch haben wir kein Recht zu verlangen, dass die wissenschaftlichen Institutionen, deren Vertreter sich in unserer Mitte befinden, Arbeiten in Mittel- und Ostasien nicht anders als durch unsere 
Vermittelung ausführen lassen. Wie die internationale Verbindung, so hat auch die Verbindung der gelehrten Institutionen und Gesellschaften unseres Landes nur den Zweck die Erforschung der in den Statuten genannten Gebiete nach Möglichkeit zu fördern und etwaige Schwierigkeiten zu beseitigen, keineswegs aber die Arbeit ausschliesslich in ihre Hände zu nehmen. Gegen Unternehmen, welche unabhängig von uns entstehen und auf unseren Beistand keinen Anspruch erheben, können wir nur dann Einwendungen haben, wenn wir durch solche Unternehmen die Interessen der Wissenschaft für geschädigt oder bedroht halten. In unserem an den Kaiserlich Russischen Konsul in Urumtči gerichteten Schreiben, von welchem wir Ihnen eine Abschrift zuzusenden die Ehre gehabt haben, war zum Schluss der Wunsch ausgesprochen, dass alle Arbeiten mit strenger Befolgung der Methoden wissenschaftlicher Forschung und mit selbstverständlicher Rücksicht gegen andere Forscher ausgeführt werden; selbstverständlich war in diesen Worten zugleich die Bitte enthalten, der Herr Konsul möge gegen die Arbeiten seines Untergebenen, wenn sie diesen Erwartungen nicht entsprechen sollten, einschreiten. In ähnlicher Weise haben wir jetzt Herrn Klementz ersucht auf H. Dr. Kochanowski einzuwirken; Herr Klementz, dessen Name mit der wissenschaftlichen Erforschung des Turfan-Gebietes untrennbar verbunden ist, hat sich bereit erklärt mit uns dafür zu sorgen, dass die Früchte seiner Arbeiten nicht durch unwissenschaftliche Ausgrabungen u. s. w. geschädigt werden; wobei er der Ansicht ist, dass eine einzelne Person in wenigen Tagen nicht etwas in „trostlosen Zustand “ versetzen kann, an dessen Zerstörung schon Generationen systematisch gearbeitet und doch für die Wissenschaft genug übrig gelassen haben. Ausserdem scheint uns kein Grund vorzuliegen H. Dr. Kochanowski zugleich jede Sammeltätigkeit für das von Herrn Klementz geleitete Museum zu untersagen.

W. Radloff

No8: TA 3269, PS of the letter of Kokhanovskii to Lecoq, 17th May 1905 / TA 2489, copy of the P.S. of the letter of Kokhanovskii to Lecoq, 17.05.1905

P.S. J'ai reçu deux papiers de l'Académie de sciences et de M. Klemenz. Dans tous les deux on m'écrit sur les travaux au Turfan, qui sont 
admissibles pour tout le monde, surtout pour ceux qui ont le plus de droits grâce aux premiers venus dans ce district - M. Regel, Klemenz, Grzimailo et beaucoup d'autres. Il y a une demande de travailler pour nos sciences et musées. Entre autres, on dit qu'il y avait une plainte de Turfan à Berlin (à l'Académie berlinoise) sur moi, qui vandalise des antiquités. Je suis content que vous connaissez mon alibi et que ces ravages à Karahochegar (comme on avait dit beaucoup de sartes de là-bas) étaient faits par vos précédents explorateurs. Comme j'avais vu, ils étaient affreux (sic!), certainement.

No9: TA 2488, note by Lecoq, 13.01.1909

Anbei Copie des P.S. eines Briefes den der stellvertretende Consul in Urumtschi, D.A. Kohanowskij, mir am 17. Mai 1905 nach Karachoğa schrieb.

Da der Brief den Beweis enthält dass die Russen ihren Vertrag mit dem Deutschen Turfan Comité umgangen haben, gebe ich ihn g.g. zu den Acten.

\section{No 10: TA 1296, letter from Oldenburg to Grünwedel, 26.08.1905}

Hochgeehrter und teurer Freund,

Erst heute komme ich dazu Ihnen zu schreiben, da ich leider sehr beschäftigt bin - unsere akademische Saison hat schon angefangen und da habe ich täglich wenigstens 12 Briefe zu schreiben und eine Menge Papiere zu lesen und zu unterzeichnen.

Da wir schon im vorigen Jahre die Reise nach Kuča beschlossen hatten und noch ohne den Namen zu kennen die Ruinen im Norden von der Stadt zur näheren Besichtigung bestimmt hatten (siehe unseren Bericht im Bulletin), so musste ich zuerst mit Klemenz, Grigorief und Berezofsky die Sache besprechen. Gestern waren die Herren bei mir und wir waren alle damit einverstanden, dass wenn Sie selbst diesen Ort durchforsten wollen und die Fresken und andere Alterthümer für Ihr Museum nehmen wollen, wir es nur freudig begrüßen können, denn so wie Sie wird es ja keiner machen können und für die Wissenschaft ist es ja gleichgültig, wo die Sachen aufgehoben werden. Berezofsky wird 
dann andere Gegenden erforschen. Er ist ein erprobter Reisender und arbeitet mit pedantischer Genauigkeit. Ausserdem ist er ein ausgezeichneter Photograph.

Wenn Sie hier sein werden, können Sie ja alles mit Berezofsky näher besprechen; ich glaube, dass er Ihnen in manchen praktischen Fragen behilflich sein kann.

Mit vielen Grüssen an die Ihren Ihr treu ergebener

S. von Oldenburg.

Wir erwarten Sie mit Ungeduld!

\section{BIBLIOGRAPHY}

Bongard-Levin, Grigorij M., Lardinois, Roland, Vigasin, Aleksej A. (éds), Correspondances orientalistes entre Paris et Saint-Pétersbourg (1887-1935), Paris, De Boccard, 2002.

Bregel, Yuri, "Central Asia. Chapter VII. in the 18th-19th Centuries", in Enyclopaedia Iranica, ed. by Ehsan Yarshater, 1992, vol. V, p. 193-205.

Bukharin, Mikhail D., "Novye dokumenty k istorii izucheniia Vostochnogo Turkestana”, Vestnik drevnei istorii, 3 (2014), p. 163-183.

Dreyer, Caren, "Russian Archaeological Explorations in Chinese Turkestan on the Turn of the 19th Century", Indo-Asiatische Zeitschrift, 12 (2008), p. 62-71.

Espagne, Michel, "Ot Turfana do Berlina: Nemetskaia razrabotka kul'turnykh transferov Tsentral'noj Azii", in Cultural Transfers in Central Asia: before, during and after the Silk Road, ed. by Shahin Mustafaev, Michel Espagne, Svetlana Gorshenina, Claude Rapin, Amridin Berdimuradov, Frantz Grenet, Paris/Samarkand, IICAS, 2013, p. 155-161.

Genovese, Lia, Proceedings (Extract) of XII International Congress of Orientalists, Rome, October 1899: Translation and Analysis, 2006: <http://idp.bl.uk/downloads/Orientalists.pdf> (accessed 18.10.2013). 
Gorshenina, Svetlana, Asie centrale: L'invention des frontières et l'héritage russo-soviétique, Paris, CNRS Editions, 2012 (Espaces et milieux).

Grünwedel, Albert, Mythologie des Buddhismus in Tibet und der Mongolei: Führer durch die lamaistische Sammlung des Fürsten E. Uchtomskij, Leipzig, Brockhaus, 1900.

Hoernle, Rudolf A. F., The Bower Manuscript: Facsimile Leaves, Nagari Transcript, Romanised Transliteration and English Translation with Notes, Calcutta, Office of the Superintendent of Government Printing, India, 1893-1912.

Hopкirк, Peter, Foreign Devils on the Silk Road: The Search for the Lost Cities and Treasures of Chinese Central Asia, London, Murray, 1980.

Litvinskit, Boris A., Terent'ev-KatanskiI, A. P., "Istoriia izucheniia”, in Vostochnyi Turkestan v drevnosti i rannem srednevekov'e. Ocherki istorii, ed. by Sergei L. Tikhvinskii, Moskva, Institut vostokovedeniia, 1988, p. 17-82.

Moiseev, Vladimir A., Rossiia i Kitaj v Tsentral'noi Azii (vtoraia polovina XIX v. - 1917 g.), Barnaul, AzBuka, 2003.

Nazirova, Nataliia N., Tsentral'naia Aziia $v$ dorevoliutsionnom otechestvennom vostokovedenii, Moskva, Izdatel'skaia firma "Vostochnaia literatura”, 1992.

O'Ldenburg, Sergej, Etiudy o liudiakh nauki, ed. by Aleksei A. Vigasin, Moskva, Rossijskii gosudarstvennyi gumanitarnyi universitet, 2012.

Popova, Irina F., "Russian Expeditions to Central Asia at the Turn of the 20th Century", in Russian Expeditions to Central Asia at the Turn of the 20th Century, ed. by Irina F. Popova, Sankt-Peterburg, Rossijskaia Akademiia Nauk, Institut vostochnykh rukopisej Rossijskoj Akademii nauk, 2008, p. 11-39.

SAnder, Lore, "Origin and Date of the Bower Manuscript, a New Approach", in Investigating Indian Art: Proceedings of a Symposium on the Development of Early Buddhist and Hindu Iconography Held at the Museum of Indian Art in May 1986, ed. by Marianne Yaldiz, Wibke Lobo, Berlin, Staatliche Museen Preussischer Kulturbesitz, 1987, p. 313-323 (Veröffentlichungen des Museums für Indische Kunst 8). 
Sundermann, Werner, "Turfan Expeditions", in Encyclopedia Iranica, 2004, online edition: <http://www.iranicaonline.org/articles/ turfan-expeditions-2> (accessed 18.10.2013).

Trautmann-Waller, Céline, "Ot iskusstva Gandkhary k nemetskim ekspeditsiiam 1902-1914 gg. na Velikom shelkovom puti. Otnosheniia mezhdu Vostokom i Zapadom soglasno Al'bertu Griunwedeliu", in Cultural Transfers in Central Asia: before, during and after the Silk Road, ed. by Shahin Mustafaev, Michel Espagne, Svetlana Gorshenina, Claude Rapin, Amridin Berdimuradov, Frantz Grenet, Paris/Samarkand, IICAS, 2013, p. $162-169$.

Vorobyeva-Desyatovskaya, Margarita I., “M. M. Berezovksy's Expedition to Kucha (1905-1908)", in Russian Expeditions to Central Asia at the Turn of the 20th Century, ed. by Irina F. Popova, Sankt-Peterburg, Rossiiskaia Akademiia Nauk, Institut vostochnykh rukopisei rossijskoi Akademii nauk, 2008, p. 65-74.

Whitfield, Susan, "Scholarly Respect in an Age of Political Rivalry", in Russian Expeditions to Central Asia at the Turn of the 20th Century, ed. by Irina F. Popova, Sankt-Peterburg, Rossiiskaia Akademiia Nauk, Institut vostochnykh rukopisei rossijskoi Akademii nauk, 2008, p. 203-219.

Wood, Frances, The Silk Road: Two Thousand Years in the Heart of Asia, Berkeley/Los Angeles, University of California Press, 2002. 